\title{
The 'gig economy': employee, self-employed or the need for a special employment regulation?
}

\section{Adrián Todolí-Signes}

Employment Law Department, Faculty of Law, University of the Balearic Islands, Palma, Spain

\begin{abstract}
Summary
The digital era has changed employment relationships dramatically, causing a considerable degree of legal uncertainty as to which rules apply in cyberspace. Technology is transforming business organisation in a way that makes employees - as subordinate workers - less necessary. New types of companies, based on the 'on-demand economy' or so-called 'sharing economy' and dedicated to connecting customers directly with individual service providers, are emerging. These companies conduct their entire core business through workers that they classify as self-employed. In this context, employment law is facing its greatest challenge, as it has to deal with a very different reality to the one existing when it was created. This article analyses the literature available about the classification of this new type of worker as an employee or as self-employed, concluding that there is a need for a new special labour regulation. It also describes and justifies the bases for this new special labour regulation.
\end{abstract}

\section{Résumé}

L'entrée dans l'ère digitale a entraîné des changements considérables dans les relations du travail, en générant dans une large mesure une incertitude juridique s'agissant des règles qui s'appliquent dans le cyberespace. La technologie transforme l'organisation de l'entreprise de telle manière que les employés - en tant que travailleurs subordonnés - apparaissent moins nécessaires. De nouveaux types d'entreprises, basées sur « l'économie à la demande », ou sur ce que l'on appelle "l'économie partagée », et qui entendent relier directement les clients à des prestataires individuels de service, sont en train d'émerger. Ces entreprises mènent l'ensemble de leurs activités principales en recourant à des travailleurs qu'elles considèrent comme des travailleurs indépendants. Dans ce contexte, le droit du travail est confronté à son plus grand défi puisqu'il a à traiter avec une réalité très différente de celle qui existait lorsqu'il a été créé. Cet article analyse la littérature disponible concernant la classification de ce nouveau type de travailleur comme salarié ou indépendant, et il conclut à la nécessité d'une nouvelle réglementation spécifique du travail. II décrit et justifie également les bases de cette nouvelle réglementation spécifique du travail.

\section{Corresponding author:}

Adrián Todolí-Signes, Departamento de Derecho del Trabajo, Facultad de Derecho, Av. dels Tarongers, 46022 València, Spain.

Email: Adrian.todoli@uv.es 


\section{Zusammenfassung}

Das digitale Zeitalter hat zu einer dramatischen Veränderung der Arbeitsbeziehungen und damit zu einer erheblichen Rechtsunsicherheit in der Frage geführt, welche Regeln im Cyberspace gelten. Die Technologie verändert Unternehmen in einer Weise, die Arbeitnehmer - als abhängig Beschäftigte - zunehmend verzichtbar werden lässt. Neue Unternehmen entstehen, die auf der Basis der „On-demand Economy” oder der so genannten "Sharing Economy” arbeiten und ihre Kunden direkt mit den einzelnen Leistungsanbietern in Kontakt bringen wollen. Diese Unternehmen lassen ihr gesamtes Kerngeschäft durch Arbeitnehmer ausführen, die sie als Selbständige ausgeben. In diesem Kontext sieht sich das Arbeitsrecht vor einer immensen Herausforderung, denn es muss sich mit einer Wirklichkeit auseinandersetzen, die zum Zeitpunkt seiner Entstehung in keiner Weise vorauszusehen war. Der Artikel analysiert die verfügbare Literatur über die Klassifizierung dieses neuen Beschäftigtentypus als Arbeitnehmer oder als Selbständiger und kommt zu dem Schluss, dass wir ein neues Arbeitsrecht brauchen. Er beschreibt und begründet ebenfalls die Grundlagen für dieses neue spezielle Arbeitsrecht.

\section{Keywords}

Outsourcing, 'sharing' economy, employment contract, self-employment, Uber economy, gig economy, economic dependency, legal concept of employee, gig economy

\section{Introduction: new types of companies and the characteristics of their business model}

The legal concept of an employee is rooted in a pre-Internet era. The advent of the digital era has changed employment relationships dramatically, causing considerable legal uncertainty about which rules apply in cyberspace. The first signs came from telework (Gabel and Mansfield, 2003: 304). However, online workers are not the only ones affected. Technology is transforming business organisations in a way that makes employees - as subordinate workers - less necessary. New types of companies, based on an 'on-demand economy' or 'sharing economy' and dedicated to connecting customers directly with individual service providers, are emerging. These companies conduct their core business completely through workers classified as self-employed. ${ }^{1}$ These new organisational possibilities, enabled by technology, might be the culmination of a process, initiated some years ago, called 'the escape from employment law' (Baylos Grau, 2000: 44).

In the literature, this new business model has been called the 'gig economy' or 'specific offline crowdwork'. Crowdwork consists of outsourcing work, traditionally carried out by an employee, to an indefinite and usually large number of people in the form of an open call (Howe, 2006: 176-179). These new technological companies thus, in theory, just match a client (demand) with a worker who will perform the task (supply). This level of outsourcing would have been impossible before the arrival of the new technologies. These companies devote their business to building an online platform (web, apps, etc.) where clients can directly find a worker or workers to perform the

1. This new organisational model has been called the 'Uber economy', but also 'on-demand economy', 'sharing economy', 'peer-to-peer economy' or '1099 economy'. Each name attempts to emphasise one characteristic of the new model. Nevertheless, all the new types of companies share one common characteristic: the existence of an online platform which connects supply and demand. See Brescia (2016). 
task. As the platform-owning companies claim to be just a database where clients and workers can find each other, they can classify workers as self-employed. As a result, in the absence of the application of employment law protection, especially the minimum wage and collective wage agreements, a client can obtain a service much cheaper than the one provided by traditional organisations (De Stefano, 2016).

In the tertiary sector, the range of businesses potentially affected is wide. Current examples include Uber - city transportation; Sandemans - guided tours; FlyCleaners - laundry; Myfixpert electronics repairs; Chefly - cooks at home; Helping - housekeeping; Sharing academy - tutor at home; or Entrenar.me - personal training. As we can see, these examples do not involve telework, but activities which require local, offline, execution. Moreover, the described companies belong to a particular sector. A client who uses these platforms is looking for a particular activity related to the platform brand. These companies do not provide a bulletin board where you could find any type of activity, but one where you can only find a specific and predefined activity. ${ }^{2}$ This characteristic is important because most of the time, the platform, within the specific type, wants to control how the work is done. As would be expected from a more traditional organisation, the company wants to keep a high level of quality when it provides its services. The platform thus has to ensure that workers provide a good service to its clients. Nevertheless, such organisations keep classifying their workers as independent contractors, or self-employed workers.

The most famous company of the specific offline crowdwork type is Uber. Uber owns a virtual platform where a user can obtain city transport. Operation is simple. After downloading the Uber app for free, any user can use it to find, by GPS, the closest driver and ask for a ride. Uber does not employ drivers or own any cars; on the contrary, Uber expects its participating drivers to do the job. Potential drivers have to send an application to Uber and pass a test in order to be authorised to participate in the platform. The authorisation process includes a request to send their driver's licence, car registration number and car insurance policy. Depending on the city, drivers may also be examined on their geographical knowledge of the city and may be interviewed by an Uber employee. A driver's vehicle has to be less than 10 years old. The price of the service is not negotiable, but set by Uber. Tips are forbidden and Uber takes between 10 per cent and 20 per cent of the price. Users can evaluate drivers and evaluations are made public for other clients (Avi Asher-Schapiro, 2014). If these are negative, Uber can deactivate a driver's access to the platform. Uber can revoke a driver's access to the platform for other reasons too, e.g. for criticising the company on social networks (Huet, 2014). Drivers are free to choose when to work and for how long. Drivers can also refuse rides, but if a task is accepted it has to be completed (Uber, 2016). Moreover, the 'drivers' manual' provided by Uber says that a driver is expected to accept all jobs. Uber will investigate - with the possibility of deactivating the driver - if too many rides are rejected. The manual invites drivers to wear professional clothes, suggests that the radio should be switched off or, if left on, should play jazz music. It also recommends opening the car door for users' convenience (Rogers, 2015: 11) and keeping an umbrella in the car, so that, in the event of rain, the user does not get wet when entering or exiting the vehicle (O'Connor v. Uber Technologies, Inc., No C-13-3826 EMC, 2015). The driver has to pay for all running expenses (petrol, insurance, taxes) and the car, and assumes all responsibility should an accident occur. Uber offers cut-price insurance to all its drivers.

2. As opposed to generic platforms where you can find any kind of service offered, e.g. TaskRabbit.com or Gigwalk.com. Here, you can employ workers inter alia for delivery work, assembling furniture, housework or warehouse audits. 
As outlined above, Uber is just one of many companies that share the same business model. Acknowledging the characteristics described, we can conclude that the model has the following characteristics:

1) Less/different labour dependency: The distinctive feature is that the new companies do not need to manage and supervise work. Using technology, companies will trust clients' work evaluation when making dismissal (deactivation) decisions (ex-ante and ex-post control). In the same sense, companies have no incentive to provide training to workers because if anyone wants to do a job they need to be sufficiently trained and ready to work. This new kind of work is configured with less (or different) subordination and more freedom to do the job. However, we can observe that the platform retains partial control over workers and the way they are supposed to work. A platform dedicated to one specific activity needs to maintain a high value image, and therefore it has a huge interest in delivering a high-quality and standardised service.

2) Economies of scale or the need for a critical mass: The business is based on accumulating a huge number of workers and users. Indeed, the fact that the platform has a large number of workers makes it unnecessary for the company to give specific instructions about schedules or working hours. The company expects clients always to be able to find an available worker thanks to the large number of them on the platform. This necessity for a critical mass can lead to a monopoly or oligopoly situation.

3) Global business: Once a platform has been built, expansion of the platform is relatively easy and cheap, allowing the typical platform to go global and deliver its services all over the world (Rogers, 2015: 10,30). Moreover, global expansion enables companies to exploit economies of scale, thereby allowing a brand to obtain the trust of users around the world. This makes it easy for the organisation to obtain the critical mass needed.

4) Something more than just a database: One of the key questions, still open to debate, is the nature of such new companies. There is no agreement on whether they only provide data (as a database) or whether they are companies providing services in a specific sector. ${ }^{3}$ In the first case, if the company owning the platform is considered a technological company that only provides data to facilitate the matching of supply and demand, it cannot be held responsible for any problems or damage caused during work. In the same sense, the company would be under no obligation to comply with any sector regulations. ${ }^{4}$ Moreover, it would be difficult to establish an employer-employee relationship between a platform and a worker who works through this platform. Regarding this question, a US Court ruled that Uber cannot be considered a technological company because if that were the case Uber would not intervene in how work is done (O'Connor v. Uber Technologies, Inc., No C-13$3826 \mathrm{EMC}, 2015)$. Alongside matching supply and demand, these new types of companies also require certain behaviour by workers in order to control the quality of the work. Moreover, these companies' revenues are not derived from access to their database, but instead from charging clients for the task (work) performed (Aloisi, 2016: 669). At the end of the day, consumers do not use these kinds of companies because they have a list of

3. In the click-wrap agreement Uber says that they are not a transportation company, therefore they disclaim any responsibility for the services provided by the drivers; see Uber Terms and Conditions, www.uber.com/legal/usa/terms

4. For example, if Uber is considered a technological company, it is under no obligation to comply with taxi regulations. 
workers who can provide the service needed, but because they want a specific service provided by a specific platform. This means that a company's reputation depends on how well workers do the job. For this reason, platforms will deactivate workers who do not perform well enough.

The aim of this article is to analyse whether these new types of workers are legally employees or self-employed, and whether there is a justified need for new special labour regulation protecting such workers. The article is structured as follows. The first part deals with the problems of using the right to control to find out whether such workers come under the scope of employment law, while the second part discusses the necessity for new kinds of protections and proposes specific regulations. The article ends with some conclusions.

\section{The impact of the new business model on labour relationships}

The appearance of this new way of doing business has given rise to two fundamental questions in the labour market. The first concerns a legal issue, questioning whether the traditional legal concept of an 'employee' is still valid in connection with this new way of working. The second question concerns policy, questioning whether there is any need to extend the scope of labour law protection, disconnecting subordinate work from such protection. What also has to be considered is whether the protection required by new workers is the same (or different) to the traditional protection accorded to subordinated work. In this sense, a new type of legal protection may be needed.

\section{The scope of employment contracts and new types of workers}

Traditionally, a self-employed worker is considered to be a person who works directly for the market, i.e. someone who offers his/her services to one or more companies without becoming part of them. Self-employed people are owners of their own organisation and have the independence needed to choose whether to accept a task. They own the tools and materials needed for the work and bear all business risks (Martínez Barroso, 2005: 122). New types of workers - working through an online platform, owning the tools and materials needed for the work, choosing when (schedule freedom), for how long (freedom of working hours) and whether to perform the work - would therefore seem to fit more into the self-employed category and less into a traditional employment relationship. In the past, labour law (in dealing with such new challenges) has expanded the definition of an 'employee' in line with new ways of working (Martínez Barroso, 2005: 106). In this regard, it has been expounded that work, when organised, determined, used and harnessed by a company, will lead to a classification as an employee even if this person enjoys a certain degree of autonomy (Rodríguez-Piñero, 1999: 21). For this reason, it will be crucial to determine whether online platform workers somehow remain within the organisational field of a company and under its control. In the USA and the UK, where the first conflicts have arisen, the literature and judicial rulings (Employment Tribunals case Mr Y Aslam vs Uber case $\mathrm{n}^{\circ}$ 2202550/2015) argue that these new companies are misclassifying their workers as self-employed. ${ }^{5}$ However, it is interesting to note that the UK ruling classifies drivers as 'workers' and not as 'employees'. (Davidov, 2005: 57-71). The arguments are as follows:

5. In Spain, the Social inspectorate has also sanctioned Uber Systems Spain for misclassification of its employees: http://economia.elpais.com/economia/2015/06/12/actualidad/1434135569_865496.html 


\section{New forms of control}

Traditional ways of monitoring and controlling the quality of work consisted of a set of elements. Companies would give specific training to an employee and specific instructions on how to perform work, and they would establish a monitoring system to check whether instructions were being followed. In these new organisations nothing like this exists.

Nevertheless, it has been argued that the monitoring and control of workers still exists, but in other forms. In the same sense, when we look at traditional employees in telework we observe that the traditional right to control is not valid for checking for new forms of dependency in the relationship. It has been said that in telework we find very different indications of dependency from the ones found in a Fordism production chain (Rodríguez Sañudo, 1999: 104; Selma Penalva, 2010: 24). Online platforms delegate monitoring to clients through an evaluation system. In this sense, companies do not need to give specific instructions or control the way the work is done to ensure quality. Instead, they allow clients to evaluate job performance, and may subsequently use such information to take decisions on dismissals (Benjamine Sachs, 2015). Indeed, even if companies only make suggestions (without giving instructions) about how to do the work, workers not following these can easily be dismissed. Expecting suggestions to be followed in their own interest, clients can give bad ratings to non-compliant workers (Aloisi, 2016: 670). The level of monitoring of these new workers is thus greater than ever, since work is observable at all times (Sprage, 2015: 18) and without cost. In traditional organisation structures, middle managers were costly, so the objective was to have an optimal level of monitoring. However, monitoring in these new organisations is now delegated, while monitoring levels are maximised. In short, the absence of a set of company instructions only means that workers are now submitted to a results obligation and not to a means obligation. There are other examples of this kind of transformation. When new companies use co-participation, monitoring focuses on work results, without workers being given any direct instructions (Rodríguez-Piñero, 1999: 37).

\section{The necessary control}

Another part of the literature establishes that, even if we acknowledge that there has been a decrease in dependency, this would not mean that workers have become self-employed. A certain level of freedom in the way the work is done will not distort the dependency relationship, and even less so when this freedom is inherent to the work (Sprage, 2015: 15). Thus, the important thing will not be how much control an employer exercises, but how much control an employer retains the right to exercise. The fact that online platforms allow workers to choose working hours and schedules (because technology makes it unnecessary to issue such instructions) does not make workers self-employed. The company could issue new instructions and workers should obey. For this reason, the fact that organisations choose not to exercise power as employers does not mean that they do not have it.

In sum, the sole use of necessary instructions does not mean that a worker becomes selfemployed (Rogers, 2015: 13). The key point will be to know whether the employer has established sufficient instructions to maintain, and with the aim of maintaining, control over a productive system. The issue is that it is not clear when a company is establishing necessary instructions to control a process. However, this conception of the employment relationship is highly related to an imbalance of power and, indeed, unbalanced power will lead to a situation where a company could choose which instructions to issue.

\section{Unbalanced bargaining power}

The literature used to argue that labour law was there to protect the economically weaker party. In that sense, employment contracts applied to 'workers' working in a socio-economic context similar 
to that of 'employees' regardless of any subordination (Rodríguez-Piñero, 1969: 59-63; González Ortega, 1987: 278; Davidov, 2002: 357; Davidov, 2005: 62; Davidov, 2016: 35-45). However, of late, the legal concept of an employment contract has shifted from a social dimension towards a legal construction which does not take into consideration any reference to an economic, social or political situation (Rodríguez-Piñero, 1999: 24). In such a context, part of the literature supports the idea that there should be a correlation between the social situation of a 'worker' (economic subordination) and the legal concept of an 'employee' (and his/her protection) (Baylos Grau, 2000: 48-49, 105). This way of thinking upholds the concept that an employment relationship should be applied to any worker who has an objectively weak bargaining position regardless of how he/she executes the work, albeit under dependency or with autonomy (Rogers, 2015: 14 and 25).

\section{Inclusion in an external organisation}

Another part of the literature understands that dependency should not be based on the existence of a set of direct instructions, but on a worker's inclusion in an external organisation (employer organisation) or, to put it another way, on the lack of his/her own organisation (Montoya Melgar, 1998). In this regard, a self-employed person will only be the one whom the company considers necessary to provide services and who also assumes business risks (Rodríguez-Piñero, 1992: 7). Conversely, when a worker is inside an external organisation where an employer establishes the rules, he/she would be an employee. Applied to the new business model, this literature leaves few doubts about the fact that the platform rules the organisation and business practices, while the worker can either accept the rules or lose his/her work. We are not talking here about the coordination between a platform and a worker (Martín Valverde, 1990: 227), but about a combination of rules imposed on workers by the company that owns the platform.

\section{A lack of entrepreneurial opportunities}

Another argument featured in a large part of the literature and defending the classification of workers as employees is the inexistence of entrepreneurial opportunities. Workers who work via an online platform provide their labour without any possibility of entrepreneurial development (Rogers, 2015: 5). This contrasts with a self-employed contractor who provides experience, training, knowledge and skills that a company does not have (Sprage, 2015: 15, 19). However, these new companies provide all their services through self-employed workers, i.e. people who do not add any special value to the job apart from their labour. Where necessary, know-how is provided by the company (Luján Alcaraz, 1991: 605-606) and transmitted to workers through 'recommendations' or necessary instructions. In fact, the only real advantage of using a self-employed worker instead of an employee would seem to be the avoidance of paying social security contributions. This results in a less costly service, although this does not seem to be a valid use of the selfemployed institution, according to the European Commission (Casas Baamonde, 1999). On the contrary, a self-employed worker is one with fair development opportunities. Real self-employed workers should have the opportunity to acquire their own clients in order to develop their business (Sprage, 2015: 10). It is thus inconsistent to classify someone who only offers his/her labour and does not have any chance of obtaining the profits inherent to a company as a self-employed entrepreneur (Marvit, 2014).

\section{Irrelevancy of certain signs in order to determine the existence of an employment relationship}

Lastly, other legal authorities argue that some evidence is not relevant when deciding whether a worker is in an employee relationship or self-employed. First, ownership of tools and materials and acceptance of business risks are a poor sign of subordination. Employment contracts were created 
at a time when the tools and materials needed for production were factories, i.e. employees could never be owners of the means of production. However, because today the means of production can be a car or a housekeeping cart, i.e. something anyone can possess, the lack of ownership of means of production is no longer a good indication of being an employee. Conversely, being their owner no longer means that you need no protection.

Indeed, in the new business model described above, the real means of production are technological. Investment in technology to create an online platform is the costly part of the means of production and, by comparison, the tools and materials owned by a worker are insignificant (Rogers, 2015: 15). At the end of the day, we have to bear in mind that the elasticity of the concept of an 'employee' has to allow it to adapt to the social reality of the time (Pérez de los Cobos, 1993: 39).

\section{Problems with fitting these new workers into the legal concept of an 'employee'}

So far, it seems that there are sufficient reasons to classify people performing offline tasks through a specific online platform as workers (not self-employed). In the UK (Employment tribunal case: Mr Y Aslam vs Uber case $\mathrm{n}^{\circ}$ 2202550/2015) and the USA, several rulings, even of the Supreme Court (Supreme Court: NLRB v Jones \& Laughlin Steel CO 301. U.S 1, 33-34 (1937)), point in this direction. The literature argues that the only reason why the employee concept has not been applied is because of the novelty and misunderstanding of the digital world (Cherry, 2009: 1106; Cherry, 2016). Indeed, in the USA, the idea of applying employment protection to all workers with an unbalanced power position has been extended (Patrick Cotter v. Lyft 13-cv-04065-VC, Auto denying the petition to dismiss the case (N.D California March 11, 2015); based on an old precedent in S.G. Borello \& Sons, INC., V. Department of Industrial Relations, 48, California, 3d 341, 351 (1989)). With this purposive interpretation of an employment contract, courts are trying to protect all workers whose autonomy is diminished (because of the power imbalance) regardless of whether subordination or dependency is found (Davidov, 2016). Nevertheless, we think this position in the legal systems of continental Europe could have two problems. On the one hand, a legal consequence of a court ruling establishing such workers as employees would make it necessary to apply all the labour rules to them. However, some of these rules just do not fit this new business model. Courts, faced with this sort of decision, would be unable to choose which rules would apply or which new solutions could be better.

On the other hand, a solution based on a court ruling would mean that, up to that moment, companies would have been misclassifying workers as self-employed, i.e. they would be subject to sanctions and other legal liabilities for breaking the law until that time.

For both reasons, we think it would be better to find a legislative solution. In a matter of legal policy, there should be an open debate over which kind of protection such workers should enjoy (Davis, 2015).

\section{A different kind of protection required for a new type of employee}

\section{New protection for a new industrial relations model}

Even if the employment relationship can be interpreted to fit the new type of workers, this does not mean that the protection needed by both the new and the old types is the same.

Rules protecting working conditions do not fully match the new business model, one of the main characteristics of which is working time flexibility. Workers are allowed to choose when and for how long they wish to work, a concept distant from traditional regulations on working hours, 
schedules, compulsory rest periods and holidays. Fixed salaries and minimum wages seem difficult to fit into a business model where a worker can also choose how long he/she is going to work (Fisher, 2015; Weber and Turcios, 2015: 12). Moreover, regulations about a pool of on-call workers or a preferential right to work in on-call jobs seem incompatible with a business which lets clients choose a specific worker, as clients will select the worker they prefer based on the public evaluations. The application of collective bargaining also has its difficulties. Bargaining entities are hard to establish on an online platform where it is unlikely that the number of workers is known and they can work for different platforms at the same time (Felstiner 2011: 183-185). Moreover, in a business where workers do not know each other, mutual trust to agree on union representatives is doubtful (Beyer, 2014; Salehi et al., 2015: 1621).

Lastly, a company has to pay for any expenses incurred by an employee under current regulations. However, in a business allowing freedom to the employee (on how to perform the job) this would seem unfair to the company. Apart from that, this business model relies on underused items owned by the worker (computer, car, Internet connection, phone, camera, and so on) and so it seems unreasonable to ask for reimbursement afterwards. However, there are some expenses which arise wholly from the work for which it might be fair to ask for reimbursement (e.g. a car's running costs).

\section{Special labour law for employees who work through an online platform}

In Spain, Italy and some other legal systems, there are different labour regulations for different professions. This is known as 'special labour law'. For example, there are special employee regulations for high-level managers, sportspeople, salespeople, artistic professions, domestic work and lawyers, among others. These special labour laws aim to adapt employment regulations to the specific necessities of a profession. By using this institution it should be simpler to include gig economy workers within the scope of the employment law, provided that those regulations incompatible with this new business model are modified to take account of the latter's circumstances.

A special labour relationship should be applied to those who perform work offline through a specific online platform, as described in this article. In this specific work, basic labour rights should be protected, without impeding the normal development of the industry. More specifically, the regulations should ensure fair representative procedures to allow self-regulation through collective agreements.

Such regulations should answer some of the following questions, although this is by no means an exhaustive list:

1) Instructions: In our opinion, the existence of direct instructions to the worker is no longer a good delimiter of an employment relationship. On the contrary, the new kind of workers, regardless of whether they receive instructions on how to perform the work or not, deserve protection (with regard to this discussion see Cruz Villalón, 1999).

To achieve a degree of legal certainty, the law proposed would have as its scope those workers who perform their activities through an online platform with less dependency (without direct instructions). This would mean that a platform could only establish the necessary instructions, leaving workers free to choose how to perform their tasks. Under this scope of application, in the case of a platform issuing specific instructions, this special labour norm would not be applicable and would require the application of the traditional employment protections.

Reduced legal dependency, as a characteristic of a special labour contract, is nothing new. The literature argues that telework is incompatible with a temporal delimitation of work (De la Villa Gil 
and García Ninet, 1990). In the same vein, a salesman, high-level manager or performing artist has less dependency, a characteristic justifying special regulation (Guerrero Vizuete, 2010: 4).

2) Freedom of schedules and working hours: The special regulations should include workers' freedom to establish their own schedules and working hours, as this is the main feature of the new industry. Employers, however, should be allowed to set a maximum number of working hours per worker per week (e.g. choosing whether the company wants a part-time or full-time worker). At the same time, the regulations should establish an overall maximum number of working hours regardless of whether they are worked for the same platform or for others. The goal of this maximum would be to encourage work-sharing and reduce unemployment.

3) Freedom to work on more than one platform: In order to promote freedom of entry into the market, the regulations should prevent exclusive agreements between one platform and a worker. Without this prohibition, it would be very easy for existing companies to monopolise all workers in a sector, leaving no possibilities for new companies to enter the market. If every worker can only be on one platform, this would have the effect of reducing competition and would reduce the chances of finding a worker available for consumers.

4) Employees' liability for damages: A lack of legal dependency has to imply a lack of company liability for damages. Traditional employees have no responsibilities in this respect because they act as a proxy of their employer, merely following his instructions. However, increased freedom in the way the work can be performed means greater responsibilities. This liability would include damage involving clients, but also damage to the online platform's reputation.

5) Minimum wage: One of the most delicate questions is the right to a minimum wage. In a way of working where a worker can choose when he/she wants to work and for how long, the existence of a guaranteed minimum wage can be costly for a company. Nonetheless, a company should pay a minimum wage for time spent working for a client. The controversy lies in waiting times. What happens when a worker is waiting for a client on an online platform?

An equitable solution could be to consider waiting time as time in which a worker is available to the company (on-call) but unproductive (mora accipiendi). For example, in Spain the labour law establishes that the employer always has to pay wages for this kind of unproductive time. However, a special regulation should qualify this obligation, compelling companies to pay for this unproductive time. It should be subject to collective bargaining. Thus, a collective agreement could reduce payment of waiting times to below the minimum wage or even remove the right to wages if deemed appropriate.

6) Reimbursement of expenses: A special employment law should allow companies to establish a series of requirements as regards the materials or tools owned by the worker in order to work via the platform. In this sense, employees could be required to possess a phone, car, computer, etc. and these 'under-utilised' assets should not be paid for by the company. However, consumable goods needed to perform the work should be reimbursed by the company (e.g. running costs). Hence, there would be a separation between fixed costs (paid by the worker) and running costs (paid by the company).

7) Subsidiary labour law: To avoid loopholes, the special norm should refer to the employment contract regulations for everything not considered by the special rule. 


\section{Conclusions}

This research analyses a new business model: a new type of company which claims to be a database via which supply and demand are matched. The companies argue that they do not have any control over workers, and therefore they are classified as self-employed. However, in this article we take a different view. There is no doubt that, on these platforms, workers enjoy more flexibility in terms of working hours and schedules, and even have more flexibility in the way they perform tasks. Nonetheless, the literature still considers them to be employees. The opposite would mean that labour law would be neglecting the subject - workers - which it has tried to protect since its very origins. Laws have to be interpreted in line with the social context of each period, making it necessary to find different formulas to continue to provide that a worker who works for a living is protected.

Nevertheless, we do not consider it appropriate to implement all existing employment contract regulations in the new business model. A worker who works offline for an online platform is subject to risks different to those of a traditional employee. Such workers therefore need a tailormade regulation. In this article, we propose the creation of a special employment relationship covering the specific aspects described above. This special regulation should be applied only to this kind of worker and should be adapted to the specific features of this new industry. This article presents a draft of this proposed regulation.

Public inaction would mean that new companies are imposing their conditions on the market. The simple fact that they can act without the costs of applying labour law means that they can provide services at a lower price than competing companies working to a traditional model.

Thus, the competitive advantages of the new business model are not necessarily the result of better organisation and greater productivity, but simply of the non-application of employment standards.

In this sense, the objective pursued by the application of labour standards (a proposed special employment contract) for this new type of worker will not only protect those who work for a living (Pérez de los Cobos, 1993: 48), but will also prevent unfair competition and social dumping (Rodríguez-Piñero, 1999: 27). Otherwise, these new companies will monopolise the market, squeezing out traditional companies.

\section{Funding}

The research presented in this article was developed within the framework of the project entitled 'The regulation of the collaborative economy' of the Spanish Ministry of Economy and Competitiveness, $n^{\circ}$ DER2015-67613-R.

\section{References}

Aloisi A (2016) Commoditized Workers. Case Study Research on Labour Law Issues Arising from a Set of 'On-Demand/Gig Economy' Platforms. Comparative Labor Law \& Policy Journal 37(3): 663-690.

Asher-Schapiro A (2014) Against Sharing. Jacobinmag, 19 September, 1. Available at: https://www.jacobinmag .com/2014/09/against-sharing/ (accessed 13 March 2017).

Baylos Grau A (2000) La 'huida' del derecho del trabajo. Tendencias y límites de la deslaborización. In: Alarcón Caracuel MR and Mirón Hernández MM (eds) El trabajo ante el cambio de siglo: un tratamiento multidisciplinar (aspectos laborales, fiscales, penales y procesales). Madrid: Marcial Pons, pp. 35-54.

Beyer JL (2014) Expect Us: online Communities and Political Mobilization. Oxford: Oxford University Press. Brescia R (2016) Regulating the sharing economy: New and old insights into an oversight regime for the peerto-peer economy. Nebraska Law Review 95: 88-144. 
Casas Baamonde et al. (1999) Trabajo y empleo. Transformaciones del trabajo y futuro del Derecho del Trabajo Europeo. Valencia: Tirant lo Blanch.

Cherry MA (2009) Working for (virtually) minimum wage: applying the fair labors standards act in cyberspace. Alabama Law Review 60(5): 1077-1110.

Cherry MA (2016) Beyond misclassification: the digital transformation of work. Comparative Labor Law \& Policy Journal 37(3): 544-577.

Cruz Villalón J (1999) El proceso evolutivo de delimitación del trabajo subordinado. In: VVAA Trabajo subordinado y trabajo autónomo en la delimitación de fronteras de derecho del trabajo: estudios en homenaje al profesor José Cabrera Bazán. Madrid: Tecnos, pp. 169-192.

Davidov G (2002) The three axes of employment relationships: A characterization of workers in need of protection. The University of Toronto Law Journal 52: 357-418.

Davidov G (2005) Who is a worker? Industrial Law Journal 34(1): 57-71.

Davidov G (2016) A Purposive Approach to Labour Law. Oxford: Oxford Monographs on Labour Law.

Davis K (2015) A New Class of Worker Could Fix The On-Demand Economy. The Crunch, 17 July. Available at: https://techcrunch.com/2015/07/17/a-new-class-of-worker-could-fix-the-on-demand-econ omy/ (accessed 13 March 2017).

De La Villa Gil LE and García Ninet JI (1990) Contrato de trabajo a domicilio. In: Borrajo DaCruz E (dic.) El Estatuto de los Trabajadores Tomo III. Madrid: Edersa: pp. 8-13.

De Stefano V (2016) The Rise of the "Just-in-Time" Workforce: On-Demand Work, Crowd Work and Labour Protection in the "Gig-Economy". ILO Conditions of Work and Employment Series no. 71, Geneva: International Labour Office.

European Commission (2016) A European agenda for the collaborative economy. Communication from the Commission to the European Parliament, the Council, the European Economic and Social Committee and the Committee of the Regions, $\operatorname{COM(2016)} 356$ final, 2 June 2016, Brussels.

Felstiner A (2011) Working the crowd: employment and labor law in the crowdsourcing industry. Berkeley Journal of Employment and Labor Law 32(1): 143-202.

Fisher D (2015) Uber says drivers oppose lawsuit that would make them employees. Forbes. Available at: http://www.forbes.com/sites/danielfisher/2015/07/09/uber-says-its-drivers-want-no-part-of-lawsuit-tomake-them-employees/\#1e45d4b1387d (accessed 16 February 2017).

Gabel J and Mansfield N (2003) The information and its Impact on the employment relationship: an analysis of the cyberspace workplace. American Business Law Journal 40(2): 301-353.

González Ortega S (1987) La difícil coyuntura del Derecho del Trabajo. Relaciones Laborales 2: 260-282.

Guerrero Vizuete E (2010) La (¿acertada?) regulación del trabajador autónomo económicamente dependiente: Análisis del artículo 11 del Estatuto del Trabajo Autónomo. Aranzadi Social 20: 149-170.

Howe J (2006) The rise of Crowdsourcing. Wired, 1 June. Available at: https://www.wired.com/2006/06/ crowds/ (accessed 13 March 2017).

Huet E (2014) Uber Deactivated A Driver For Tweeting A Negative Story About Uber. Forbes. Available at: http://www.forbes.com/sites/ellenhuet/2014/10/16/uber-driver-deactivated-over-tweet/\#545e7b8a36c8 (accessed 16 February 2017).

Irani L and Six S (2013) Turkopticon: interrupting worker invisibility in Amazon Mechanical Turk. Changing Perspectives. Paris, 1-10. Available at: https://hci.cs.uwaterloo.ca/faculty/elaw/cs889/reading/turkopti con.pdf (accessed 13 March 2017).

Luján Alcaraz J (1991) La contratación privada de servicios y el contrato de trabajo: contribución al estudio del ámbito de aplicación del Derecho del Trabajo. Murcia: Universidad de Murcia.

Luján Alcaraz J (2001) Reflexiones sobre el papel del Derecho del Trabajo en la actual revitalización del trabajo autónomo. Aranzadi Social 15: 227-234. 
Martín Valverde A (1990) El discreto retorno del arrendamiento de servicios. In: VVAA Cuestiones actuales de Derecho del Trabajo. Estudios ofrecidos por los catedráticos de Derecho del Trabajo en homenaje al Profesor Manuel Alonso Olea. Madrid: Ministerio de Trabajo y Seguridad Social, pp. 236-260.

Martínez Barroso MR (2005) Trabajo autónomo y trabajo subordinado. Delimitación, Análisis y Propuestas de Reforma. Estudios Financieros 273: 71-144.

Marvit M (2014) How Crowdworkers became the ghosts in the digital machine. The Nation, 5 February 2014. Available at: https://www.thenation.com/article/how-crowdworkers-became-ghosts-digital-machine/ (accessed 13 March 2017).

Montoya Melgar A (1998) Sobre el trabajo dependiente como categoría delimitadora del Derecho del Trabajo. Civitas. Revista española de derecho del trabajo 91: 709-724.

Pérez de los Cobos F (1993) El trabajo subordinado como tipo contractual. Documentación Laboral 39: $29-48$.

Rodríguez-Piñero M (1966) La dependencia y la extensión del ámbito del Derecho del Trabajo. Revista de Política Social 71: 40-73.

Rodríguez-Piñero M (1992) La huida del Derecho del Trabajo. Relaciones Laborales 12: 5-25.

Rodríguez Sañudo F (1999) La integración del teletrabajo en el ámbito de la relación laboral. In: Rodríguez Sañudo F VVAA Trabajo subordinado y trabajo autónomo en la delimitación de fronteras del derecho del trabajo: estudios en homenaje al profesor José Cabrera Bazán. Madrid: Tecnos, pp. 103-122.

Rogers B (2015) Employment as a Legal Concept. Legal Studies Research Papers Series. Philadelphia: Temple University.

Sachs B (2015a) Uber and lyft: customer reviews and the right-to-control. On labor.

Sachs B (2015b) A new category of worker for the on-demand economy? On labor.

Sala Franco T and López Mora F (1990) Contrato de trabajo. Comentarios a las leyes laborales. El Estatuto de los Trabajadores. Volume I.

Salehi N et al. (2015) We Are Dynamo: Overcoming Stalling and Friction in Collective Action for Crowd Workers. CHI'15. Available at: http://hci.stanford.edu/publications/2015/dynamo/DynamoCHI2015.pdf (accessed 13 March 2017).

Selma Penalva A (2010) Propuestas y reconsideraciones sobre el teletrabajo. Anales de Derecho 28: 20-45. Sprage R (2015) Worker (Mis)Classification in the Sharing Economy: Square Pegs Trying to fit in Round Holes. A.B.A. Journal of Labor \& Employment Law 31, Wyoming: University of Wyoming, pp. 53-76.

Uber (2016) Uber Terms and Conditions. No. 10 November 2016. Available at: www.uber.com/legal/usa/ terms (accessed 16 February 2017).

Weber PM and Turcios EN (2015) Uber hits a speed bump in California: labor commissioner rules driver is an employee. Employee Benefit Plan Review, September 70(3): 3-13. 